\title{
Ethics and Morality in the Vienna Circle
}

Anne Siegetsleitner

Workshop Five Years MCMP: Quo Vadis, Mathematical Philosophy?

Munich, June 2, 2016

\section{Introduction}

Thank you for the invitation to talk about ethics and morality in the Vienna Circle in this workshop about the future of mathematical philosophy. For several reasons, that is not to be taken for granted. The first pertains to me as a philosopher: I am not a mathematical philosopher. A second reason is that mathematical philosophy is not closely associated with morality or ethics. Moreover, the Vienna Circle itself is not closely associated with morality or ethics, either. However, I hope that these reservations will vanish or at least be diminished by the end of my talk. In keeping with the purpose of this workshop, I aim to provide some input from the past by giving a selective overview and discussing with you whether this is of more than antiquarian interest.

As you know, from the Vienna Circle and other European philosophical groups (especially the Berlin Group) emerged a philosophical movement that now is known as Logical Empiricism, Logical Positivism or Neopositivism. The characterization as well as the relationship of this movement to ethics and morality are not considered difficult without reason. Nevertheless, the questions that arose in this context are worth reconsidering. This may be surprising to someone who still holds at least one of the two main prejudices concerning the Vienna Circle that I will concentrate on. If we take the term "morality" to refer to a certain common practice of daily life you are all sufficiently familiar with and the term 
"ethics" to the philosophical inquiry of morality, these prejudices may be formulated in the following way.

(1) Most members of the Vienna Circle as human beings and citizens were not interested in morality.

(2) As far as some members regarded morality in a philosophical way, that is, practiced ethics, they supported the standard view of logical empiricist ethics.

I will explain what I mean by "the standard view of logical empiricist ethics" at due time. I ask you for some patience.

The important issue for now is that these two theses constitute the prevailing view on the role and conception of ethics and morality in the Vienna Circle. In my monograph on this topic (Siegetsleitner 2014a), I disprove this view and reject it as too undifferentiated.

Although the monograph treats the ethical main topics and positions as those developed in the respective personal and cultural contexts, I cannot address these questions today. Instead, in the first part of my talk, I will present central reasons for my rejection of the prevailing view. In the last part, I put forth for discussion some theses about why these findings are relevant for mathematical philosophy, or rather, for mathematical philosophers.

\section{Scientific Humanism}

As far as the first thesis of the prevailing view is concerned, it is of great interest that most members of the Vienna Circle not only were interested in morality but that the core members of the circle even shared an enlightened and humanistic version of morality. This further motivated them to a certain respective practical engagement. They all endorsed what Carnap called “scientific humanism” in his "Intellectual Autobiography” published in 1963 (Carnap 1963a). By the way, Feigl had already used the expression in 1949 (Feigl 1949 [1981, p. 368]).

Scientific humanism is a moral position comprised of the following four principles. 
1. Human living conditions and life should be improved.

2. Whatever can be done to improve human living conditions and life is the task of human beings themselves. (“man has no supernatural protectors or enemies”)

3. Many sufferings can be avoided.

4. Science is one of the most valuable instruments in the improvement of human living conditions and life (Carnap 1963a, p. 83).

The first principle states the fundamental normative dimension of this moral stance. The other principles identify whose task this is, what can be achieved and the importance of science in this endeavour. Carnap writes, “[...] mankind is able to change the conditions of life in such a way that many of the sufferings of today may be avoided and that the external and the internal situation of life for the individual, the community, and finally for humanity will be essentially improved” (Carnap 1963a, p. 83). Scientific humanism considers science one of the most valuable tools in achieving these aims. Hence, Carnap continues: “[...] all deliberate action presupposes knowledge of the world, that the scientific method is the best method of acquiring knowledge and that therefore science must be regarded as one of the most valuable instruments for the improvement of life” (Carnap 1963a, p. 83). As far as we know, this moral position was shared by most members of the Vienna Circle, as Carnap stated in his autobiography. ${ }^{1}$

This common view can also be found in the program pamphlet of the Verein Ernst Mach Scientific Conception of the World: The Vienna Circle published in the year 1929. Written by Neurath, Hahn and Carnap, it is also called "the manifesto". It clearly states:

The attitudes toward questions of life also showed a noteworthy agreement, although these questions were not in the foreground of themes discussed within the Circle. For these attitudes are more closely related to the scientific world-conception than it might at first glance appear from a purely theoretical point of view. For instance, endeavours

\footnotetext{
1 “A number of my friends in the Vienna Circle probably shared these views in their essential features; but in detail, naturally, there were important differences” (Carnap 1963a, p. 83).
} 
toward a new organization of economic and social relations, toward the unification of mankind, toward a reform of school and education, all show an inner link with the scientific world-conception; it appears that these endeavours are welcomed and regarded with sympathy by the members of the Circle, some of whom indeed actively further them (Neurath/Hahn/Carnap 1929 [1973, p. 305]).

Scientific humanism was closely linked to the scientific world-conception, and most members of the circle were united in endorsing it. Since scientific humanism is a very general attitude, it was interpreted and specified in several ways. As far as political engagement was concerned, Neurath, for example, combined it with a socialist political agenda, Schlick with a more liberal one.

In addition, the manifesto outlined the historical roots of this moral attitude. It invokes eudaimonism, liberalism, and utilitarianism. In addition to antimetaphysical research and interdisciplinarity, the manifesto generally stresses principles of this-worldliness and lifeaffinity (Lebensverbundenheit) (Stadler 1985, p. 117). These principles are pronounced in scientific humanism.

Because science is regarded as of prime importance to this conception of morality and logic as central to science, even Carnap’s logical work is no retreat from engagement but one form of relevant practice. The well-known sentences in the last paragraph of the manifesto hence read:

Of course not every single adherent of the scientific world-conception will be a fighter. Some, glad of solitude, will lead a withdrawn existence on the icy slopes of logic; some may even disdain mingling with the masses and regret the "trivialized" form that these matters inevitably take on spreading. However, their achievements too will take a place among the historic developments. We witness the spirit of the scientific world-conception penetrating in growing measure the forms of personal and public life, in education, upbringing, architecture, and the shaping of economic and 
social life according to rational principles. The scientific world-conception serves life, and life receives it. (Neurath/Hahn/Carnap 1929 [1973, p. 306]).

Let me conclude: Quite contrary to the first thesis of the prevailing view, most members of the Vienna Circle as human beings and citizens were highly interested in morality, namely in a certain conception of morality that was called scientific humanism. Its holders are convinced that it is the task of humanity itself to improve human living conditions and life and that science is one of the most valuable means to this improvement.

Much of analytic philosophy and supposedly mathematical philosophy still is explicitly or implicitly - motivated by this general moral position as a background assumption. Therefore, some feel they are part of a morally good or even the best movement, which they see as inherently linked to analytic methods. Not surprisingly, an enemy to these methods is sometimes regarded as more than a philosophical enemy. However, let us postpone this for discussion.

\section{The Standard View}

I will now turn to the standard view of moral philosophy generally ascribed to the Vienna Circle in the second thesis of the prevailing view. As I have mentioned, this thesis is often meant as a reproach.

The standard view of logical empiricist moral philosophy is characterized by (1) first, the acceptance of descriptive empirical research - but this research is not regarded as genuine moral philosophy - and (2) second, by the rejection of normative and substantial ethics. Metaethics remains the only legitimate way of doing moral philosophy. In addition, and (3) third, within metaethics, logical empiricist moral philosophy is characterized by an extreme form of non-cognitivism.

By "an extreme form of non-cognitivism", I mean the thesis that there is no room for knowledge and/or rationality in moral matters. For more details, please see my monograph. 
However, not all members supported the standard view of logical empiricist ethics. As I have shown in the monograph, Carnap's position is nearest to the standard view. Menger's, Neurath’s and Frank’s positions already depart in some respects. Schlick’s, Kraft's and Feigl's views, finally, deviate the most from it. In contrast to the commonly held picture of ivory tower logicians and metaethicists, some members of the Vienna Circle even practiced applied ethics. To my own surprise, Schlick even used this very expression, which was common in the Ethical Movement at the time.

In this respect, a short note about the Ethical Movement and its importance is adequate. The Ethical Movement was initiated in the last decades of the $19^{\text {th }}$ century. Its aim was a secular humanist moral life, moral education, and philosophy. In 1890, the movement launched the International Journal of Ethics, known as Ethics today (see Siegetsleitner 2014b). Carnap and Schlick were members of the Ethical Community in Vienna. They took an active part in this movement ${ }^{2}$. The initiator of the Ethical Movement in Austria was the Viennese philosophy professor Friedrich Jodl. Although he is mentioned in the manifesto, he is unduly nearly forgotten today. This important relationship between logical empiricists and the Ethical Movement still deserves closer consideration.

Let me now explain the deviations from the standard view in more detail by looking at the position of some core members. Due to time limits, I cannot talk about all the members I have mentioned.

\section{Proponents and Deviants}

\subsection{Carnap (1891-1970)}

Because Carnap is the member of the Vienna Circle whose conception of moral philosophy is closest to the standard view, I will present relevant aspects of his position first. In his wellknown article "Überwindung der Metaphysik durch logische Analyse der Sprache"

\footnotetext{
${ }^{2}$ Stebbing gave ethical lectures at the Sunday meetings of the South Place Ethical Society (e.g., on 10 December 1939 and 19 April 1942).
} 
(“Elimination of Metaphysics through Logical Analysis of Language”, Carnap 1931/32), one finds nearly all elements of this view. In the English-speaking world, this perspective was widely spread by Ayer's Language, Truth, and Logic (1936) and Carnap’s own Philosophy and Logical Syntax (1935). The latter contains the published version of three lectures Carnap gave at the University of London during his first visit to Great Britain in 1934. By the way, it was Susan Stebbing who invited Carnap to give these lectures (see Siegetsleitner 2015). Stebbing and Carnap share the humanistic approach as can be seen, for example, through her conviction that morality does not require otherworldly sanctions or religion (see, e.g., her “Ethics and Materialism”, 1939). Prior to this position, Carnap was more closely associated with phenomenological and Neo-Kantian approaches regarding questions of value (see, e.g., Mormann 2006 and Siegetsleitner 2014a). The traces of these approaches can be found in Carnap’s Aufbau (§152). I will not elaborate on this but instead on Carnap’s position during and after his time as a member of the Vienna Circle.

First, in Carnap’s conception of morality during his Viennese time, the content of morality is simply determined by individual decisions. This is why Hans Zeisel could report in his "Erinnerungen an Rudolf Carnap” about an incident in Vienna:

There, students asked Carnap: "Do you really mean that morality is something everyone has to decide on for himself?”, and he said: "Yes". Hence, they were angry and said: "That means, if you liked to, you could murder and this would be moral?”, and he answered: "Yes, in my sense, indeed, but luckily I have no inclination to murder” (Zeisel 1993, p. 220, transl. by A.S.).

In "Elimination of Metaphysics through Logical Analysis of Language”, Carnap expressed his position that all value statements were merely expressions of a Lebensgefühl, moral ones included. However, this was not a conclusion reached by logical analysis but a presupposition. We should take his “in my sense” very seriously. 
In Philosophy and Logical Syntax, the little book from 1935, one can read in the same vein:

But actually a value statement is nothing else than a command in a misleading grammatical form. It may have effects upon the actions of men, and these effects may either be in accordance with our wishes or not; but it is neither true nor false. It does not assert anything and can neither be proved nor disproved (Carnap 1935, p. 24). What value statements express, are permanent emotional or volitional dispositions (Carnap 1935, pp. 29 f.).

That the crucial points are taken for granted still holds true for Carnap's later work in the logical treatment of value statements. As you might know, in his reply to Kaplan (Carnap 1963b) on value statements Carnap developed a formal language for pure optatives and introduced the optative-operator “utinam”. Unfortunately, Carnap could not give an answer either to the question of whether we need such a language for our moral practice or to the question of whether this is an adequate interpretation of the moral vocabulary used in our moral practice.

Carnap’s account of individualistic non-cognitivism ultimately turns out to be his interpretation of value statements right from the beginning. This is not problematic as long as one is aware of it. Carnap knew about this:

Everyone has the right to determine the interpretation of any statement he makes; and the reader has to accept the interpretation of the author unless he finds a discrepancy between the interpretation explicitly stated by the author and that implied in the way in which the author uses the statement or argues about it (Carnap 1963b, p. 1000).

One has to accept it as a possible interpretation, however, not to adopt it!

Carnap holds an individualistic version of moral epistemic decisionism. According to this position, individual decisions determine whether a moral statement is right or wrong. Expressing this view, he could say in 1964 that what is morally good or bad is "the individual 
decision of any human according to his conscience or value feeling or however one may call it” (Carnap 1964 [1993, p. 146]).

On this basic assumption, there was little room for normative or substantial ethics. Regardless, Carnap did not use it at all, although in his later contribution, there opened up room for logic and rationality.

\subsection{Otto Neurath (1882-1945)}

Let me continue with Neurath, although I will be rather brief about his work. Neurath was convinced that science, and up to a certain extent, philosophy could make a major positive difference to people’s living conditions and happiness. His philosophical work has an obvious moral purpose, with scientific humanism as the relevant background. However, although he was concerned about the miserable living conditions of men and women, he restricted his academic work to providing tools for the social sciences to describe and finally improve these circumstances. He developed his famous felicitology using formal and mathematical economic methods.

In philosophy, Neurath worked against harmful speculations. He saw Stebbing as an ally when he points out: "It is not only by accident that L. Susan Stebbing wrote on the one hand a book criticizing highly metaphysical speculations of modern physicists and on the other hand her Thinking to some Purpose and her Ideals and Illusions” (1941, p. 132). Here we find again a connection to Stebbing, who was an active member of the Unity of Science Movement.

Although Neurath was in favour of formal and mathematical methods, their application had to prove their usefulness to his moral and political enterprise. Therefore, he let Carnap know in a letter in 1945 a few days before his sudden death: "In our movement I sometimes have the feeling that some members avoid discussing problems of decision, action etc and are using analysis as a kind of escape from life. THAT IS NOT MY APPROACH” 
(Neurath to Carnap, 22 September 1945, Vienna Circle Archive, Haarlem (NL), Inv.-No. 223).

It was certainly not the approach of Schlick, either, to whom I turn now.

\subsection{Moritz Schlick (1882-1936)}

Schlick deviates from the standard view in fundamental respects. I will restrict myself to his stance on the legitimacy of normative ethics.

Basically, Schlick followed the ideal of a wise man, suggesting a worthwhile way of life to people. His first book, Lebensweisheit (The Wisdom of Life, published in 1908), already deals with ethical questions. In 1930, he published Fragen der Ethik (Problems of Ethics, English translation 1939), which mostly is about moral psychological issues like psychological hedonism. Nevertheless, and surprisingly, the last chapter proclaims a moral principle on a eudaimonist basis: “Be ready for happiness!” (1939, p. 187). On the same basis, his posthumously published work Natur und Kultur (Nature and Culture, 1952) discusses questions of politics, war, economics, law and technology. It belongs in the category of applied ethics. In Schlick’s manuscript “Ethik des modernen Lebens. Eine Kritik der Gegenwärtigen Kultur” from the academic year 1927/28 the term “Angewandte Ethik” [applied ethics] is used:

Wenn ich also sage, dass wir es in diesen Vorlesungen mit angewandter Philosophie zu tun haben werden, mit angewandter Ethik, so heisst dies, das [sic!] wir uns zum Ziel setzen nicht die wissenschaftliche Aufgabe der Erforschung der Prinzipien menschlichen Handelns, sondern dass wir uns beschäftigen werden mit ihrer Anwendung auf besondere, konkrete Fälle des menschlichen Daseins. Nicht auf erdachte, ausgeklügelte Fälle - denn damit blieben wir immer noch in der Sphäre der Theorie - sondern auf wirkliche Verhältnisse des menschlichen Lebens (Schlick [Ethik des modernen Lebens], Vienna Circle Archive, Haarlem (NL), Inv.-Nr. 10/A. 18, 2 f.). 
We have to realise that Schlick practiced normative and applied ethics on a eudaimonist basis. This demonstrates that Schlick believed in the legitimacy of normative ethics, therein differing from the logical empiricist standard view of moral philosophy.

\subsection{Victor Kraft (1880-1975)}

The last member whose contribution to ethics I want to discuss is Victor Kraft. In contrast to many members of the circle, Kraft had not studied physics or mathematics, but rather philosophy, geography, and history. In 1914, he habilitated in theoretical philosophy. The topic of his thesis was Weltbegriff und Erkenntnisbegriff, and Jodl was one of his supervisors (Topitsch 1960, p. III f.).

Kraft remained an independent thinker within the circle. Ernst Topitsch writes about Kraft's position in the circle: “[...], he had already reached maturity, both as a man and as a philosopher, when the group was formed round Moritz Schlick in the 20’s and he had by then brought to completion important works entirely of his own. [...], he was far too independent to start again as a disciple” (Topitsch 1976, p. xi), Kraft maintained a critical attitude, for example, towards physicalism and the idea of a unity of science, as Rutte has shown (Rutte 1973, p. 7).

In 1937, Kraft published the first edition of his Grundlagen einer wissenschaftlichen Wertlehre (Foundations of a Scientific Value Theory) in the series Schriften zur wissenschaftlichen Weltauffassung. The editors were Schlick and Frank. The second, an essentially revised edition, followed in 1951. This second version was published in English under the title Foundations for a Scientific Analysis of Value in 1981.

Already in the first edition, Kraft distinguishes between the factual content (Sachgehalt) and the value character (Wertcharakter) of value concepts used in value judgements. In Kraft's account, this value character does not express an individual statement, but an impersonal (überpersönlich) and general view: “A value judgment means [...]: the 
command to a statement to an object, generally and anonymously, not of a certain person for certain people” (Kraft 1937, p. 164, transl. by A.S.).

According to Kraft, there are pure value concepts like "good” or "bad”. However, in most concepts, an additional component is present: a factual content. This component provides the criteria for impersonal judgement. In these cases, Kraft speaks of specialized value concepts. In his theory, moral concepts always belong to this category. If the criteria for these impersonal judgements are empirical, depending on the moral approach, there is plenty of room for rational argument and knowledge. This position is far beyond an extreme noncognitivism.

In addition, Kraft made numerous attempts to come up with a rational justification of why everybody is bound to certain impersonal moral views. In one of these attempts he regards acting according morality as a necessary condition for reaching aims decreed by human nature. In another, he refers to basic requirements of culture. Unfortunately, all attempts are full with flaws. Nonetheless, he kept trying up until old age. Therefore, when one talks about Kraft's rational justifications of morality in more detail, one has to state which attempt is discussed.

To cut this long story short: Based on these findings, it is wrong that the members of the Vienna Circle generally rejected normative/substantial ethics or endorsed an extreme form of non-cognitivism.

\section{Lessons for Today?}

Why is this historical retrospective important for contemporary and future philosophy? Which are the lessons to learn or aspects to consider? Let me put forth the following points for discussion. Some are more general, some especially important for mathematical philosophers.

(1) Philosophers who think that following Carnap and being suspicious about normative/substantial ethics and/or cognitivism is the only option for staying close to the Vienna Circle’s tradition are mistaken. Even some core members supported 
a wider range of options. Needless to say, even more options were considered than I could present today.

(2) Shared background assumptions unite. In the Vienna Circle, these shared background assumptions did not primarily concern the conceptions of ethics or the use of formal methods, but rather morality itself. Scientific humanism was the common frame of reference. As a general frame, it is open to specific interpretations and supplements. However, we should keep in mind that it is exactly this shared scientific humanism that determines in some respects which philosophical approaches in the inquiry of morality could be considered adequate. A metaethical approach looking for good arguments of why a divine will determines morality was out of question. It would have not made sense within the frame of scientific humanism. Perhaps scientific humanisms is open to taking a divine will into consideration when it comes to motivation. Apart from this general exclusion of options, additional premises led to specific metaethical positions like an individualistic non-cognitivism.

I deem it important for mathematical philosophers to learn that methodological viewpoints were not constitutive in this respect. It was not the method but the account of what morality is about that united the circle in the first place.

(3) A philosopher who engages in ethics cannot dismiss his or her conception of morality entirely as soon as it comes to questions of adequacy. The concentration on logic or other formal methods might not provide an escape. For mathematical philosophers, this means that in many cases, deciding on a method means at the same time deciding on a fundamental assumption about what morality is about or how moral language works. Take the translation of moral statements into pure optatives as an example. Frankly, I consider those mathematical philosophers good 
ones who not only know about the strength of their methods, but also about their limits and the respective background assumptions. Methods are like fishing nets: they have a determining influence on which fish you will catch. In general, you have to be a very good mathematical philosopher to be able to distinguish useful application from useless. To be sure, this is true for an applicant of any method.

(4) I presume that the ethical contributions of the Vienna Circle would have been improved by a discussion of ethical issues in the meetings of the circle and to a certain extent by the application of formal methods, too. Perhaps one of you young mathematical philosophers will come up with such improved theories.

References

Ayer, A. J. 1936: Language, Truth, and Logic. London.

Carnap, R. 1928: Der logische Aufbau der Welt. Berlin.

Carnap, R. 1931/32: “Überwindung der Metaphysik durch logische Analyse der Sprache”, in: Erkenntnis 2 (4), pp. 219-241.

Carnap, R. 1935: Philosophy and Logical Syntax. London.

Carnap, R. 1963a: “Intellectual Autobiography”, in: Schilpp, P. A. (ed.): The Philosophy of Rudolf Carnap. Chicago, pp. 1-84.

Carnap, R.1963b: “Reply to Abraham Kaplan on Value Judgment”, in: Schilpp, P. A. (ed.): The Philosophy of Rudolf Carnap. Chicago, pp. 999-1013.

Carnap, R. 1964: “Interview mit Rudolf Carnap”, in: Carnap, R. 1993: Mein Weg in die Philosophie. Stuttgart, pp. 134-148.

Feigl, H. 1949: “Naturalism and Humanism”, in: American Quarterly 1, pp. 135-148.

(Reprint in: Feigl, H. 1981: Inquiries and Provocations. Selected Writings 1929-1974. Dordrecht, pp. 366-377.

Kraft, V. 1937: Die Grundlagen einer wissenschaftlichen Wertlehre. Vienna.

Kraft, V. 1951: Die Grundlagen einer wissenschaftlichen Wertlehre. 2nd edition. Vienna.

Kraft, V. 1981: Foundations for a Scientific Analysis of Value. Ed. by H. L. Mulder. Dordrecht, Boston, London. (Vienna Circle Collection 15)

Mormann, Th. 2006: "Werte bei Carnap”, in: Zeitschrift für philosophische Forschung 60 (2), pp. 169-189.

Neurath, O. 1941: "Universal Jargon and Terminology”, in: Proceedings of the Aristotelian Society. New Series 41, pp. 127-148.

Neurath, O./Hahn, H. /Carnap R. 1929: Wissenschaftliche Weltauffassung. Der Wiener Kreis. Wien. (English translation in: Neurath, M./Cohen, R. S. (eds.) 1973: Empiricism and Sociology. Vienna Circle Collection, vol 1. Dordrecht p. 299-318.)

Rutte, H. 1973: "Viktor Kraft. Eine philosophische Standortbestimmung”, in: Conceptus 7 (21-22), pp. 5-8.

Siegetsleitner, A. 2014a: Ethik und Moral im Wiener Kreis. Zur Geschichte eines engagierten Humanismus. Vienna, Cologne, Weimar. 
Siegetsleitner, A. 2014b: “On Friedrich Jodl’s ‘Morals in History”, in: Ethics 125, pp. $211-$ 213.

Siegetsleitner, A. 2015: "Susan Stebbing and the Vienna Circle on Moral Philosophy”, in: Buchhammer, B. (ed.): Neuere Aspekte in der Philosophie: aktuelle Projekte von Philosophinnen am Forschungsstandort Österreich. Vienna, pp. 206-212.

Schlick, M. 1908: Lebensweisheit. Versuch einer Glückseligkeitslehre. Munich.

Schlick, M. 1930: Fragen der Ethik. Vienna. (English translation as Problems of Ethics, 1939)

Schlick, M. 1939: Problems of Ethics. New York.

Schlick, M. 1952: Natur und Kultur. Vienna.

Stadler, F. 1985: “Popularisierungsbestrebungen im Wiener Kreis und 'Verein Ernst Mach'”, in: Dahms, H.-J. (ed.) 1985: Philosophie, Wissenschaft, Aufklärung. Beiträge zur Geschichte und Wirkung des Wiener Kreises. Berlin, New York, pp. 101-128.

Stebbing, S. 1939a: Thinking to Some Purpose. Harmondsworth.

Stebbing, S. 1939b: "Ethics and Materialisms”, in: Ethics 50 (1), pp. 35-44.

Stebbing, S. 1941: Ideas and Illusions. London.Topitsch, E. 1960: “Zum Geleit”, in: Topitsch, E. 1960 (ed.): Probleme der Wissenschaftstheorie. Festschrift für Victor Kraft. Vienna, pp. III-VI.

Topitsch, E.1976: “Introduction”, in: Kraft 1981, pp. xi-xv.Zeisel, H. 1993: "Erinnerungen an Rudolf Carnap”, in: Haller, R./Stadler, F. (ed.) 1993: Wien - Berlin - Prag. Der Aufstieg der wissenschaftlichen Philosophie. Vienna, pp. 218-223.

All rights reserved. 